\title{
Florida's Property Tax Reform: Implications for Your Tax Bill from Proposed Constitutional Changes ${ }^{1}$
}

Rodney L. Clouser²

\section{Introduction}

Many people want to know what impact proposed constitutional changes will have on their taxes. People are interested in how much savings they might realize from the proposed amendment, and for some this may influence whether they vote yes or no on the amendment. In reality, there is no foolproof method to answer the question of how much property tax reduction each individual will personally realize. The estimated 2008-2013 impact of approximately $\$ 12.4$ billion in reduced property taxes over the next five years if the constitutional amendment passes sounds like a lot of money and it is. "Potential savings" for any individual property owner however may be relatively small.

No one knows for sure the exact individual savings from the proposed amendments. Nor do they know with certainty what future millage rates will be; exactly what the future taxable value of a particular property will be; or how many homeowners in Florida will sell or buy a homestead and take advantage of the portability feature if the constitutional amendment passes.

However, it is possible to estimate what direction future individual reductions or savings might take if the proposed amendments are adopted by making a few simple assumptions. These assumptions will be noted within the individual analysis for each primary component of the proposed constitutional change. Other publications in this series are FE703, FE704, FE705, and FE707 which can be found at the EDIS website (http://edis.ifas.ufl.edu).

Before proceeding, an additional word of caution for the analysis provided in this publication needs to be considered. The analysis is based on hypothetical examples that make assumptions regarding values of property and millage rates. The examples are not representative of any single taxpayer. The examples are not estimates of taxes due for any single taxpayer but rather hypothetical examples of changes that

1. This is EDIS document FE706, a publication of the Food and Resource Economics Department, Florida Cooperative Extension Service, Institute of Food and Agricultural Sciences, University of Florida, Gainesville, FL. This document is part of a series of documents on Florida Property Tax Reform. Published December 2007. Please visit the EDIS website at http://edis.ifas.ufl.edu.

This factsheet should not be considered as a comprehensive assessment of property tax changes adopted or proposed by the legislature. Some details of actual or proposed changes are not discussed due to space limitations. This factsheet represents the interpretation by the author(s) of the most significant changes. This factsheet is not intended as a replacement for personal knowledge about actual or proposed changes but is a guide to inform the public on property tax issues.

2. Rodney L. Clouser, Professor and Extension Public Policy Specialist, Food and Resource Economics Department, Florida Cooperative Extension Service, Institute of Food and Agricultural Sciences, University of Florida, Gainesville, FL.

The Institute of Food and Agricultural Sciences (IFAS) is an Equal Opportunity Institution authorized to provide research, educational information and other services only to individuals and institutions that function with non-discrimination with respect to race, creed, color, religion, age, disability, sex, sexual orientation, marital status, national origin, political opinions or affiliations. U.S. Department of Agriculture, Cooperative Extension Service, University of Florida, IFAS, Florida A. \& M. University Cooperative Extension Program, and Boards of County Commissioners Cooperating. Larry Arrington, Dean 
would occur if the proposed constitutional amendment is passed by Florida voters.

\section{Proposed Constitutional Changes}

\section{Tangible Personal Property}

The constitutional amendment calls for a $\$ 25,000$ exemption on tangible personal property. To assess the impact of this exemption for an individual it is assumed that the countywide millage rate is $\$ 16$ per $\$ 1000$ of value. The $\$ 16$ millage rate is appropriate to evaluate the amendment and is an approximation of the median countywide millage rate for the state's 67 counties in 2006.

If the entire $\$ 25,000$ tangible personal property tax exemption applies and the millage rate is 16 mills, projected tax savings would be $\$ 400$. According to the Florida Senate analysis, there were just over one million entities with taxable amounts of $\$ 25,000$ or less in Florida who filed tangible personal property tax returns in 2007 with a taxable value of $\$ 4.6$ billion. That equates to an average value of just over $\$ 4,600$ per return and based on a 16 mill tax rate would equate to an average savings in tangible personal property tax of about $\$ 74$. Therefore, a reasonable estimate of an individual's tax reduction if they are eligible for the $\$ 25,000$ tangible personal property tax exemption is between $\$ 74$ and $\$ 400$. Most taxpayers who have no rental or business property will not be affected by this component of the constitutional amendment.

The Florida Senate estimates the total reduction in property taxes with the exemption of $\$ 25,000$ in tangible personal property at $\$ 922$ million between 2008-09 and 2012-13. The reduction is $\$ 525$ million for non-school units of government and \$397 million for school levies.

\section{Increasing the Homestead Exemption from $\$ 25,000$ to $\$ 50,000$}

The proposed constitutional amendment would increase the current homestead tax exemption from $\$ 25,000$ to $\$ 50,000$. However, the increase would only apply to homesteads with an assessed value greater than $\$ 50,000$. The way the increased homestead exemption is structured is that the exemption would apply to the first $\$ 25,000$ of assessed value, taxes would be paid on the next $\$ 25,000$ of value (assessed value between $\$ 25,000$ and $\$ 50,000$ ), and the remainder of the exemption $(\$ 25,000)$ would be applied to the assessed value over $\$ 50,000$ (up to $\$ 75,000$ in assessed value). In addition, the increased exemption from $\$ 25,000$ to $\$ 50,000$ does not apply to school tax levies.

To assess the impact of this exemption on an individual, it is assumed the countywide millage rate is $\$ 16$ per $\$ 1000$ of value. A further assumption is that this millage rate is composed of $\$ 7.50$ per $\$ 1000$ in school district millage (a rate slightly below the median school millage in 2006). The remainder of the millage rate is $\$ 8.50$ per $\$ 1000$ of value for all other governmental units.

In the first scenario assume the homestead has a just value of $\$ 300,000$ and an assessed value of $\$ 200,000$. This implies a Save Our Homes (SOH) homestead differential of $\$ 100,000$. To estimate current taxes, the $\$ 25,000$ homestead exemption is subtracted from the assessed value $(\$ 200,000)$, resulting in a taxable value of $\$ 175,000$ dollars. The total taxes due can be calculated by multiplying the taxable value $(\$ 175,000)$ by the millage rate per $\$ 1000$ of value (175 times $\$ 16$ ). Under current law, this will result in a tax bill of $\$ 2800$ and the $\$ 25,000$ exemption will reduce the tax bill by $\$ 400$. Under the proposed constitutional amendment the taxes due would change. The first $\$ 25,000$ is exempt from taxes of all governmental units. This results in the same savings (\$400) as the current system. The next $\$ 25,000$ in taxable value is fully taxed. The next $\$ 25,000$, however, is exempt from all taxes except school levies. The value of this additional $\$ 25,000$ exemption is calculated by multiplying 25 times $\$ 8.50$ (the millage rate for all governmental units except schools). This results in a further reduction of $\$ 212.50$. The total tax bill would be $\$ 2587.50$. The total savings under this scenario from increasing the homestead exemption to $\$ 50,000$ as proposed in the amendment is $\$ 212.50$.

In a second scenario assume that the homestead has a just value of $\$ 150,000$ and an assessed value of $\$ 60,000$. This implies a Save Our Homes (SOH) homestead differential of $\$ 90,000$. To estimate 
current taxes, the $\$ 25,000$ homestead exemption is subtracted from the assessed value $(\$ 60,000)$, resulting in a taxable value of $\$ 35,000$ dollars. Total taxes due can be calculated by multiplying the taxable value $(\$ 35,000)$ by the millage rate per $\$ 1000$ of value (35 times $\$ 16$ ). Under current law, this will result in a tax bill of $\$ 560$ and the $\$ 25,000$ exemption will reduce the tax bill by $\$ 400$. Under the proposed constitutional amendment the taxes due would change. The first $\$ 25,000$ is exempt from taxes of all governmental units. This results in the same savings (\$400) as the current system. The next $\$ 25,000$ in value is fully taxed. The next $\$ 25,000$ is exempt from all taxes except school levies. In this instance, however, the homeowner only has an assessed value of $\$ 60,000$. Additional tax savings can be accumulated only on the difference between $\$ 60,000$ and $\$ 50,000$ (remember the value between $\$ 25,000$ and $\$ 50,000$ is fully taxed). The additional tax savings can be calculated multiplying 10 times $\$ 8.50$ (the millage rate for all governmental units except schools). This results in a further reduction of $\$ 85$. Total tax reductions are $\$ 485$. The total tax bill would be $\$ 475$. The total savings under this scenario from increasing the homestead exemption to $\$ 50,000$ as the constitutional amendment proposes is $\$ 85$.

In both of the scenarios discussed, the second $\$ 25,000$ exemption (on the assessed value between $\$ 50,000$ and $\$ 75,000$ ) results in less of a savings since the exemption does not apply to school taxes. Finally, it needs to be remembered that if the property has an assessed value of $\$ 50,000$ or less, there are no additional savings to the homeowner. The total tax reduction remains $\$ 400$, the same as the current system.

The Florida Senate estimates the total reduction in property taxes with the additional $\$ 25,000$ in homestead exemptions at $\$ 4.67$ billion between 2008-09 and 2012-13. The total reduction is for non-school units of government and the additional $\$ 25,000$ exemption has no impact on school levies.

\section{Portability}

The proposed constitutional amendment allows for statewide portability. The maximum dollar amount for portability is $\$ 500,000$. Therefore, the $\$ 500,000$ is a cap on portability. If the just value of the new homestead purchased is greater than the just value of the previous homestead, the entire differential is transferable up to $\$ 500,000$. However, individuals who purchase a new homestead with a just value less than the prior homestead sold will also benefit from portability but on a proportional basis. If the just value of the new property is less than the just value of the prior property sold, the portability value is calculated by dividing the just value of the new property by the just value of the property sold. This percentage is then multiplied by the assessed value of the prior (sold) homestead. If the difference in the just value of the new homestead and the assessed value of the new homestead is greater than $\$ 500,000$, the assessed value will be adjusted so that the difference is $\$ 500,000$.

In the first scenario assume that the purchase of a more expensive homestead property with a just (market) value of $\$ 300,000$ and an assessed value of $\$ 200,000$. And assume that the previous homestead property had a just value of $\$ 200,000$ and an assessed value of $\$ 75,000$. Also, retain the previous assumption of a countywide millage rate of $\$ 16$ per $\$ 1000$ of value. It must be remembered that the portability aspect of the proposed constitutional change applies to taxes levied for all units of government, including schools. To isolate the savings from portability, ignore the homestead tax exemptions. Since the just value of the new property is greater than the previous property, the entire $\mathrm{SOH}$ differential is transferable up to $\$ 500,000$. Under the current tax structure, the total taxes if this move was made can be calculated by multiplying 300 times $\$ 16$, or the total taxes would be $\$ 4,800$. Under the proposed changes, $\$ 125,000$ in portability is transferable (differential is equal to $\$ 200,000$ minus $\$ 75,000)$. The value of the portability can be calculated by multiplying 125 times $\$ 16$, or $\$ 2000$. Total taxes paid under the proposed constitutional change would equal $\$ 2,800$ and total taxes would be reduced by $\$ 2,000$.

In the second scenario assume you purchase a less expensive homestead (downsizing) with a just (market) value of $\$ 200,000$. And assume your previous homestead had a just value of $\$ 300,000$ and an assessed value of $\$ 75,000$. Also, retain the previous assumption of a countywide millage rate of 
$\$ 16$ per $\$ 1000$ of value. It must be remembered that the portability aspect of the proposed constitutional change applies to taxes levied for all units of government, including schools. To isolate the savings from portability ignore the homestead tax exemptions. Under the current structure, the total taxes if this move was made can be calculated by multiplying 200 times $\$ 16$, or total taxes would be $\$ 3,200$. Under the proposed changes, taxes are calculated by dividing the just value of the new homestead $(\$ 200,000)$ by the just value of the previous homestead $(\$ 300,000)$, or .67 . This result (.67) is then multiplied by the assessed value of the previous homestead $(\$ 75,000)$ and this equals the assessed value of the new homestead $(\$ 50,250)$. The difference in the just value of the new homestead and the assessed value of the new homestead cannot exceed $\$ 500,000$. In this specific example, this difference is $\$ 149,750$ ( $\$ 200,000$ minus $\$ 50,250$ ). Total taxes paid under the proposed constitutional change would equal $\$ 804$ (50.25 multiplied by $\$ 16$ ). Total taxes under the proposed constitutional change would be reduced by $\$ 2396$.

Remember, the value of exemptions such as the homestead exemption was not considered in the portability analysis, but these exemptions will also apply to the new homestead. The Florida Senate estimates the total reduction in property taxes with portability at $\$ 5.63$ billion between $2008-09$ and 2012-13. The total reduction is $\$ 3.27$ billion for non-school units of government and $\$ 2.36$ billion on school levies. There is very limited information available on when people move and where they might move to within the state (within the county or outside of the county). Therefore, the statewide estimates of portability impacts are difficult to compute.

\section{Percent Non-Homestead Cap}

The final component of the proposed constitutional change is the non-homestead cap. The non-homestead cap is similar to the current $\mathrm{SOH}$ limitation, but the cap for non-homesteads is established at 10 percent rather than the 3 percent cap established for homesteads. The 10 percent assessment cap for non-homestead property does not apply to school district levies. It applies to residential, commercial and industrial property. Non-homestead residential property is defined as residential property containing nine or fewer units (i.e., no large apartment units with greater than nine units).

For discussion purposes, some of the previous assumptions will be retained: the property is a house (e.g., a second home in Florida) with a $\$ 300,000$ market (just) value, the countywide millage rate is $\$ 16$ per $\$ 1000$ of value, the millage rate is composed of $\$ 7.50$ per $\$ 1000$ in school district millage and $\$ 8.50$ per $\$ 1000$ for all other governmental units, and it is assumed that the market value of the property has been increasing 12 percent per year and will retain this rate of increase into the future.

Based on the 12 percent increase in valuation, the property tax for the next year would be based on a value of $\$ 336,000$. Technically, the market (just), assessed, and taxable valuable would be identical for this property because there are no exemptions available to the property owner. Under the current system, taxes due would be $\$ 5,376$ (336 times $\$ 16$ ). Under the proposed constitutional amendment, the increase in the assessed value is limited to 10 percent, or an assessed and taxable value of $\$ 330,000$.

General government taxes would be $\$ 2,805$ (330 times \$8.50). Remember, the assessment limit does not apply to school taxes (levies). Therefore, the amount of taxes paid is calculated by multiplying the assessment without the 10 percent limit. School taxes would be $\$ 2,520$ (336 times $\$ 7.50$ ). Total taxes paid under the proposed amendment would be $\$ 5,325$. The total savings in taxes paid, compared to the current situation, would be $\$ 51$. Of course, the higher the percentage increase above the 10 percent cap and the higher the millage rate, the greater the savings.

The Florida Senate estimates the total reduction in property taxes with the 10 percent assessment cap at $\$ 1.16$ billion between $2009-10$ and 2012-13. The total reduction is totally for non-school units of government (school levies are not impacted). A significant difference for this component of the proposed constitutional amendment is that it does not take effect until the 2009-2010 tax year. 


\section{Summary and Conclusion}

The proposed constitutional amendments have a proposed statewide impact over the 2008-2013 period of about $\$ 12.4$ billion. However, as the above analysis demonstrates, potential savings for any individual tax payer may be relatively small. The one exception relates to the concept of portability. The examples constructed for portability would potentially save $\$ 2,000$ or more. However, there are no accurate methods of measurement of how many people sell homes and move within the state in any given year and would benefit from this component of the constitutional changes.

Many people may assume that since they have some individual estimate of how much they might save if the constitutional amendment passes, they now know "how they will vote" on the constitutional amendment. However, that would be an inaccurate assumption. Before making the decision to support or not support the constitutional amendment, taxpayers need to know more than just individual impacts. Individuals also need to know the collective impact of the proposed amendment on their community: city, county, school, etc. This is important because the collective impact affects the services provided and the quality of life in the broader community.

\section{References}

Florida Senate. 2007. 2007-D Special Session Summary of Legislation Passed. http://www.flsenate.gov/Publications/2007D/Senate/ reports/summaries/pdf/sessum07D.pdf. Visited website November 2007.

Florida Senate. 2007. The Florida Senate Professional Staff Analysis and Economic Impact Statement.

http://www.flsenate.gov/Publications/2007D/Senate/ reports/summaries/pdf/sessum07D.pdf. Visited website November 2007.

Florida Senate. 2007. Senate Joint Resolution 2-D, Enrolled. http://www.flsenate.gov/cgi-bin/ view_page.pl?Tab=session $\&$ Submenu $=1 \& \mathrm{FT}=\mathrm{D} \& \mathrm{Fil}$ $\mathrm{e}=\mathrm{sb} 0002$ Der.html $\&$ Directory $=$ session $/ 2007 \mathrm{D} /$ Senate $/$ bills/billtext/html/. Visited website November 2007.

Florida Senate. 2007. Senate Joint Resolution 4-D, Enrolled. http://www.flsenate.gov/cgi-bin/ view_page.pl?Tab=session $\&$ Submenu $=1 \& F T=D \& F i l$ $\mathrm{e}=$ sb0004Der.html $\&$ Directory $=$ session $/ 2007 \mathrm{D} /$ Senate $/$ bills/billtext/html/. Visited website November 2007.

Florida Senate. 2007. Senate Joint Resolution 6-D, Enrolled. http://www.flsenate.gov/session/ index.cfm?Mode $=$ Bills $\&$ SubMenu $=1 \& \mathrm{Tab}=$ session $\&$ BI_Mode $=$ ViewBillInfo\&BillNum $=0006 \&$ Chamber $=$ Senate $\&$ Year $=2007 \mathrm{D} \&$ Title $=\% 2 \mathrm{D} \% 3 \mathrm{EBill} \% 2520 \mathrm{Inf}$ o\%3AS\%25200006\%2D\%3ESession\%25202007D. Visited website November 2007.

Florida House of Representatives. 2007. Senate Property Tax Proposal - County By County Analysis. http://www.myfloridahouse.gov/FileStores/Web/ HouseContent/Approved/Announcements/Uploads/ Documents/ SENATE\%20County\%20by\%20County\%20v2.pdf. Visited website November 2007. 